\title{
$17: 35853236-35867457$
}

National Cancer Institute

\section{Source}

National Cancer Institute. 17: 35853236-35867457. NCI Thesaurus. Code C42523.

Physical location of IGFBP4_Gene 